\title{
MATHEMATICAL MODEL OF THE RECEIVING PATH OF DIGITAL COMMUNICATION LINES
}

Vitaly G. Dovbnya,

Southwest State University, Kursk, Russia, vit_georg@mail.ru

Dmitry S. Koptev,

Southwest State University, Kursk, Russia, d.s.koptev@mail.ru
Keywords: mathematical model, radio receiving system, digital communication lines, demodulator device, carrier wave recovery device, frequency instability of local oscillator oscillations, clock synchronization device, potential noise immunity

\begin{abstract}
Modern trends in the development of digital communication lines of fixed information transmission services, as well as the characteristics of continuous channels today determine the noise immunity of radio receiving systems. The main directions of its increase in terms of the radio receiving device as a whole and the demodulator device in particular are as follows: reducing the frequency and nonlinear distortions of the signal in the linear path, increasing the stability and purity of the spectral line of oscillations of local oscillators, increasing the selectivity for the mirror and combination channels of reception, compensation for intersymbol and cross - polarization interference, improving the functioning of the automatic gain control device (reducing static and dynamic errors), improving the quality of the functioning of the carrier wave recovery device and the clock synchronization device. Taking into account all of the above factors in order to increase the overall noise immunity of a digital communication line is a very difficult and urgent task, the solution of which must begin with the development of a mathematical model of a continuous digital communication line channel. This article discusses the radio receiving path of a digital communication line in an urban environment. The obtained analytical expressions are aimed at interpreting the processes of converting digital signals in the structural elements of radio receiving systems. The originality of the mathematical model developed in the article lies in the fact that it additionally, in comparison with similar models, takes into account the following number of factors: frequency instability and phase fluctuations of oscillations of the local oscillator synthesizer, dynamic and static errors in the operation of automatic gain control devices, carrier vibration recovery devices and devices clock synchronization of radio receiving systems of digital signals.
\end{abstract}

Information about authors:

Vitaly G. Dovbnya, Doctor of Technical Sciences, Associate Professor, Professor of the Department of Space Instrumentation and Communication Systems, Southwest State University, Kursk, Russia

Dmitry S. Koptev, 3-nd year post-graduate student, lecturer at the Department of Space Instrumentation and Communication Systems, Southwest State University, Kursk, Russia

\section{Для цитирования:}

Довбня В.Г., Коптев Д.С.. Математическая модель приёмного тракта цифровых линий связи // Т-Сотm: Телекоммуникации и транспорт. 202।. Том I5. №5. C. $52-57$

For citation:

Dovbnya V.G., Koptev D.S. (202I) Mathematical model of the receiving path of digital communication lines. T-Comm, vol. 15, no.5, pp. 52-57. (in Russian) 


\section{Introduction}

Nonlinear signal distortions are one of the significant factors limiting the possibility of increasing the noise immunity of radio receiving systems of digital communication lines with multiposition types of signal modulation [1]. The signals with quadrature amplitude modulation are especially sensitive to this type of distortion, the ends of the vectors of the realizations of which are located at the nodes of a square lattice. The degree of influence of this type of distortion depends on the type and position of the signal and is determined by the amplitude characteristic of the transmitting path of the digital communication lines and the dynamic range of the linear path of the radio receiving systems [2].

The presence of side receiving channels reduces the dynamic range of the radio receiving systems, since it shifts upward the lower boundary of the working section of the amplitude characteristic of its linear path. The current state of the theory and practice of designing radio receivers of the HF and UHF range makes it possible to create radio receiving systems with a suppression level of side receiving channels of at least $45 \mathrm{~dB}$, which is sufficient in most cases to receive multi-position signals.

The influence of phase fluctuations of oscillations of the radio receiving systems heterodyne is manifested in the form of additional fluctuations in the phase of the carrier oscillation of the received signal.

The purpose of the article is to develop an analytical model of the receiving path of digital communication lines, which allows one to take into account the frequency instability and phase fluctuations of oscillations of the synthesizer of oscillations of local oscillators, dynamic and static errors in the operation of the automatic gain control device, as well as the carrier recovery and clock synchronization devices.

\section{Materials and research methods}

The research methods used in the article are based on the foundations of the theories of electrical communication, potential noise immunity, synchronization of demodulators, systems for recovery of the carrier wave and clock synchronization. As a criterion for the reliability of the received symbols in this work, when developing a mathematical model, the maximum likelihood criterion for a communication channel with memory was used. Also, when constructing the model, it was assumed that the resulting frequency response of the linear path of radio receiving systems is determined by the characteristics of the filters matched to the signal.

It is known from telecommunication theory that under the conditions of equality of the prior probabilities of the transmitted symbols, the minimum of the average error probability is provided by the receiving system, which makes decisions based on the maximum likelihood criterion.

Without violating the generality of reasoning, in the future in the article a fair assumption is made that the radio wave propagation channel has an equivalent complex impulse response $\dot{G}_{C}(t, \tau)$.

For a channel with memory, which is a continuous channel, the maximum likelihood criterion provides for signal processing over the analysis interval determined by the formula:

$$
T_{a}=T+T_{C} \approx T(q+1),
$$

$T_{C}$ - channel memory; $q$ - number of signal elements affecting the received implementation [3].

On this interval, the envelope of the received signal realization can be written in the following form:

$$
\begin{aligned}
& \dot{U}(t)=\int_{\tau_{0}}^{(q+1) T+\tau_{0}} \dot{G}_{C R}(t) \dot{S}_{r}(t-\tau) d \tau+\dot{\zeta}(t)+\dot{N}_{R}(t) \\
& \dot{G}_{C R}(t)=\int_{-\infty}^{\infty} \dot{G}_{C}(t, \tau) \dot{G}_{R}(t-\tau) d \tau \text { - equivalent impulse re- }
\end{aligned}
$$

sponse of a channel formed by a radio wave propagation channel and a linear path of radio receiving systems;

$\dot{G}_{R}(t)$ - impulse response envelope of the linear path of radio receiving systems;

$$
\dot{\zeta}(t)=\sum_{\substack{k=-q, k \neq 0}}^{q} \int_{\tau_{0}}^{(q+1) T+\tau_{0}} \dot{G}_{C R}(\tau) \dot{S}_{r}(t-\tau+k T) d \tau-\text { c plex }
$$

intersymbol noise envelope;

$$
\dot{N}_{R}(t)=\int_{\tau_{0}}^{(q+1) T+\tau_{0}} \dot{G}_{R}(\tau) \dot{N}(t-\tau) d \tau-\text { complex envelope of }
$$

additive gaussian interference;

$\dot{N}(t)=\dot{N}_{\xi}(t)+\dot{N}_{\zeta}(t)$ - complex envelope of additive Gaussian interference with a correlation function of the form:

$$
B_{N}(\tau)=\frac{N_{0}}{T} \frac{\sin (2 \pi \tau / T)}{2 \pi \tau / T}
$$

$N_{0}$ - one-way spectral density of additive quasi-white noise;

$\dot{N}_{\xi}(t)$ - c plex envelope of thermal noise (external and internal with respect to the radio receiving system);

$\dot{N}_{\varsigma}(t)$ - c plex envelope of interference from other radio electronic means on the main, side and adjacent reception channels of the radio receiving system [4].

For an equivalent low-frequency channel, the maximum likelihood criterion has the following form:

$$
\begin{aligned}
& \int_{\tau_{0}}^{(q+1) T+\tau_{0}} \operatorname{Re}\left[\dot{U}(t) \dot{C}_{r}(t)\right] d t-\mu_{0} \frac{E_{r}}{2}>\int_{\tau_{0}}^{(q+1) T+\tau_{0}} \operatorname{Re}\left[\dot{U}(t) \dot{C}_{p}(t)\right] d t-\mu_{0} \frac{E_{p}}{2}, \\
& \dot{C}_{r}(t)=\int_{\tau_{0}}^{(q+1) T+\tau_{0}} \dot{G}_{C R}(\tau) \dot{S}_{r}(t-\tau) d \tau+\dot{\zeta}(t) ; \\
& \dot{C}_{p}(t)=\int_{\tau_{0}}^{(q+1) T+\tau_{0}} \dot{G}_{C R}(\tau) \dot{S}_{p}(t-\tau) d \tau+\dot{\zeta}(t) ; \\
& E_{r}=\int_{\tau_{0}}^{(q+1) T+\tau_{0}}\left|\dot{C}_{r}(t)\right|^{2} d t, E_{p}=\int_{\tau_{0}}^{(q+1) T+\tau_{0}}\left|\dot{C}_{p}(t)\right|^{2} d t-\text { gnal }
\end{aligned}
$$

envelope energy corresponding to the $\mathrm{r}$ - and $\mathrm{p}$-symbol sequences; $\mu_{0}, \tau_{0}$ - median attenuation and total delay time of a signal in a radio propagation channel; $r, p=1,2, \ldots, M^{q}[5]$. 
Due to the fact that the complexity of the implementation of the optimal solver in accordance with (4) grows exponentially with an increase in the channel memory, in practice, suboptimal methods of signal reception are used with a decision made at each clock interval.

For an equivalent low-frequency channel satisfying the condition $\mathrm{T}_{\mathrm{C}}>>\mathrm{T}$ (without intersymbol interference), the CMF will take the following form:

$$
\begin{aligned}
& \int_{\tau_{0}}^{T+\tau_{0}} \operatorname{Re}\left[\dot{U}(t) \dot{C}_{r}(t)\right] d t-\mu_{0} \frac{E_{r}}{2}> \\
& >\int_{\tau_{0}}^{T+\tau_{0}} \operatorname{Re}\left[\dot{U}(t) \dot{C}_{p}(t)\right] d t-\mu_{0} \frac{E_{p}}{2}, r \neq p \\
& \dot{C}_{r}(t)=\int_{\tau_{0}}^{T+\tau_{0}} \dot{G}_{C R}(\tau) \dot{S}_{r}(t-\tau) d \tau ; \\
& \dot{C}_{p}(t)=\int_{\tau_{0}}^{T+\tau_{0}} \dot{G}_{C R}(\tau) \dot{S}_{p}(t-\tau) d \tau \\
& E_{r}=\int_{\tau_{0}}^{T+\tau_{0}}\left|\dot{C}_{r}(t)\right|^{2} d t^{\prime} \quad E_{p}=\int_{\tau_{0}}^{T+\tau_{0}}\left|\dot{C}_{p}(t)\right|^{2} d t-\text { env ope en- }
\end{aligned}
$$

ergy of the signals corresponding to the $\mathrm{r}-$ and $\mathrm{p}-$ symbols, $(r, p=1,2, \ldots, M)$.

In a channel with intersymbol distortions, reception in accordance with (5) is associated with significant energy losses. The influence of intersymbol distortions can be significantly weakened if the decision on the transmitted symbols is taken as a result of the analysis of the signal realizations at the output of the continuous channel at the sample points (single sample method). For this, in the radio receiving system, the signal is passed through an equalizing filter, the frequency response of which is selected in such a way that the signal at the output of the equivalent low-frequency channel is equal to zero at times determined by the following expression:

$$
\begin{aligned}
& \tau_{0}+(k+i) T, \\
& i= \pm 1, \pm 2, \ldots
\end{aligned}
$$

In this case, at the moments of reference $\tau_{0}+k T$ the voltage at the output of the continuous channel is determined only by the realization of the signal corresponding to the $\mathrm{k}$-th transmitted symbol.

To fulfill this requirement, it is necessary and sufficient that the frequency response of the resulting equivalent low-frequency channel satisfies the Nyquist condition [5]:

$$
\dot{H}_{N}(\Omega)= \begin{cases}\sum_{k=-\infty}^{\infty} \dot{H}\left(\Omega+k \frac{2 \pi}{T}\right)=\text { const, } & |\Omega| \leq \pi / T, \\ 0, & |\Omega|>\pi / T,\end{cases}
$$

$\dot{H}(\Omega)$ - frequency response of an equivalent low-frequency channel.

If the original channel bandwidth exceeds $2 \pi / T$, it is necessary to construct such an equalizing filter so that condition (7) is fulfilled. The most often used equalizing filter is a transverse $\mathrm{T}$ - or $\mathrm{T} / 2$ interval filter (harmonic equalizer), the coefficients of which are optimized according to the criterion of the minimum mean-square error caused by the action of intersymbol distortion and noise.

It should be noted that the use of the above harmonic equalizer, although it minimizes the variance of the resulting interference at the sample points, does not provide a minimum probability of reception error, since the sample values of intersymbol distortion are not Gaussian and independent. Therefore, demodulators use a sample-whitening matched filter that ensures the independence of the sample values.

For an equivalent low-frequency channel with a characteristic of the form $\sum_{k=-\infty}^{\infty} \dot{H}_{\Sigma}\left(\Omega+k \frac{2 \pi}{T}\right)$, not accepting zero values in the area $|\Omega| \leq \pi / T$, такой the filter is a cascading matched filter having a frequency response proportional to $\dot{H}_{T}^{*}(\omega)$, and a harmonic corrector whose gains are proportional to the Fourier coefficients in the expansion:

$$
\sum_{k=0}^{\infty} b_{k} e^{-j k \Omega T}=1 / \sum_{k=-\infty}^{\infty}\left|\dot{H}_{\Sigma}\left(\Omega+k \frac{2 \pi}{T}\right)\right|^{2} .
$$

\section{Results and discussion.}

The analysis of trends in the development of digital communication lines of fixed services and the characteristics of a continuous channel that determine the noise immunity of radio receiving systems, carried out in [6-7], suggests that the main conceptual directions for increasing the noise immunity in terms of the radio receiving device are:

1) reduction of frequency and nonlinear signal distortions in the linear path;

2) increasing the stability and purity of the spectral line of oscillations of heterodyne;

3) increased selectivity for adjacent and side (mirror and combination) reception channels.

To obtain analytical expressions that interpret the processes of converting digital signals in the structural elements of radio receiving systems, let us consider the generalized block diagram of the receiving path of a digital communication line, shown in Figure 1.

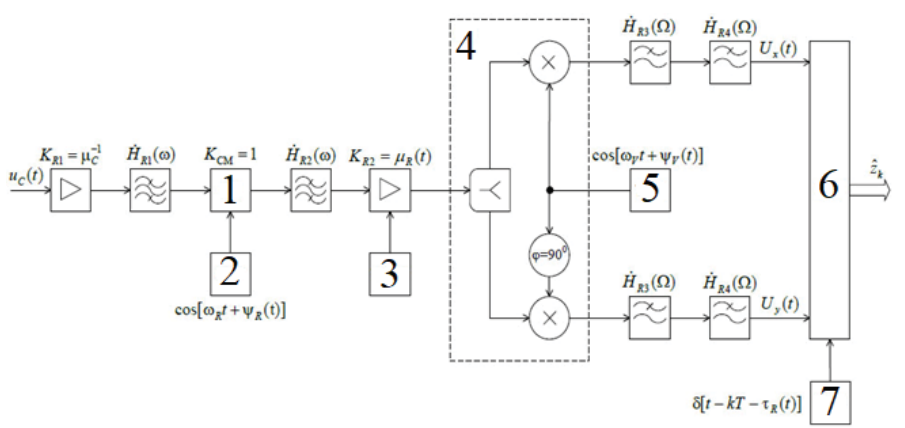

Figure 1. Generalized block diagram of the receiving path of the digital communication line: 1 - mixer; 2 - synthesizer of heterodyne oscillations; 3 - automatic gain control device; 4 - quadrature converter; 5 - carrier frequency recovery device; 6 - clock synchronization device; 7 - decision making device 
The generalized block diagram of the receiving path of a digital communication line contains the following elements:

- $\quad$ input amplifier with gain $K_{R 1}=\mu_{0}^{-1}$, providing the required amplification of the high-frequency radio signal;

- bandpass filter preselector with transfer characteristic $\dot{H}_{R 1}(\omega)$, ensuring the allocation of the required frequency band of the radio signal;

- $\quad$ mixer and synthesizer of local oscillator oscillations that transfer the spectrum of a high-frequency radio signal to an intermediate frequency;

- $\quad$ intermediate frequency filter with transfer characteristic $\dot{H}_{R 2}(\omega)$, intermediate frequency spectrum separator;

- $\quad$ variable gain amplifier $K_{R 2}$ and an automatic gain control device, providing a given signal level at the input of the demodulating device;

a quadrature converter that separates the signal into in-phase and quadrature components;

- $\quad$ carrier recovery device;

- $\quad$ signal matched filters with transfer characteristic $\dot{H}_{R 3}(\Omega)$, providing maximum signal-to-noise ratio;

- $\quad$ equalizing transversal filters with transfer characteristic $\dot{H}_{R 4}(\Omega)$, providing highly accurate reproduction of signal frequency characteristics;

- $\quad$ clock synchronizer;

- $\quad$ a decision-making device, the result of which is an assessment of the level of received signals and the formation of an output sequence of symbols.

The resulting frequency response of the linear path of the radio receiving system is determined, first of all, by the characteristic matched with the signal and equalizing transverse filters, which can be mathematically written in the following form:

$\dot{H}_{R}(\omega)=\dot{H}_{R 1}(\omega) \dot{H}_{R 2}\left(\omega-\omega_{R 0}\right) \dot{H}_{R 3}\left(\Omega-\omega_{0}\right) \dot{H}_{R 4}\left(\Omega-\omega_{0}\right) \approx$ $\approx \dot{H}_{R 3}\left(\Omega-\omega_{0}\right) \dot{H}_{R 4}\left(\Omega-\omega_{0}\right) \cdot$

Then the signal at the input of the decision making device of the radio receiving system can be written in the form:

$$
\begin{aligned}
& \dot{U}(t)=U_{x}(t)+j U_{y}(t), \\
& U_{x}(t)=\mu_{R}(t)\left\{d G_{\Sigma}\left[t-k T+\tau_{0}(t)-\tau_{R}(t)\right] \times\right. \\
& \times\left\{m_{r} \cos \left[\psi_{0}(t)-\psi_{R}(t)-\psi_{V}(t)\right]-n \sin \left[\psi_{0}(t)-(11)\right.\right. \\
& \left.\left.\left.-\psi_{R}(t)-\psi_{V}(t)\right]\right\}+\zeta_{x}(t)+N_{R x}(t)\right\} ; \\
& U_{y}(t)=\mu_{R}(t)\left\{d G_{\Sigma}\left[t-k T+\tau_{0}(t)-\tau_{R}(t)\right] \times\right. \\
& \times\left\{n_{r} \cos \left[\psi_{0}(t)-\psi_{R}(t)-\psi_{V}(t)\right]+m_{r} \sin \left[\psi_{0}(t)-(12)\right.\right. \\
& \left.\left.\left.-\psi_{R}(t)-\psi_{V}(t)\right]\right\}+\zeta_{y}(t)+N_{R y}(t)\right\} ; \\
& G_{\Sigma}(t)=\frac{1}{2 \pi} \int_{-\infty}^{\infty} \dot{H}_{T 1}(\Omega) \dot{H}_{C}(\Omega) \dot{H}_{R 3}(\Omega) \dot{H}_{R 4}(\Omega) \exp (j \Omega t) d \Omega
\end{aligned}
$$

- hannel impulse response envelope;

$\mu_{R}(t)$ - instability of the output signal of the automatic gain control device;
$\tau_{R}(t)=\tau_{R 0}+v_{R}(t)$ - clock cycle instability;

$\tau_{R 0}$ - integral error of setting the position of clock pulses;

$v_{R}(t)$ - clock timing jitter;

$\omega_{R 0}=\omega_{0}-\omega_{V 0}-$ average value of the tuning frequency of the synthesizers of oscillation of local oscillators;

$\omega_{V 0}$ - average value of the free vibration frequency of the carrier recovery device;

$\psi_{R}(t)=\omega_{R 0} \delta \omega_{R} t+\varphi_{R}(t)$ - phase of the output oscillation of LO oscillator synthesizers;

$\delta \omega_{R}$ - integral relative frequency instability of heterodyne oscillator synthesizers;

$\varphi_{R}(t)$ - phase jitter of LO oscillator synthesizers;

$\psi_{V}(t)=\varphi_{V 0}+\varphi_{V}(t)$ - phase of the output waveform of the carrier recovery device;

$\varphi_{V 0}$ - integrated error in setting the phase of the output oscillation of the carrier recovery device;

$\varphi_{V}(t)$ - phase jitter (dynamic phase error) of the output wobble of the carrier recovery device;

$\zeta_{x}(t), \zeta_{y}(t)$ - intersymbol noise quadrature envelopes;

$N_{R x}(t), N_{R y}(t)$ - envelopes of quadrature components of Gaussian interference with zero mean and variance $\sigma_{N}^{2}=N_{0} B_{R}$;

$$
B_{R}=\frac{1}{2 \pi} \int_{-2 \pi / T}^{2 \pi / T}\left|\dot{H}_{R 3}(\Omega) \dot{H}_{R 4}(\Omega)\right|^{2} d \Omega-\mathrm{r} \text { dio bandwidth. }
$$

Expressions (10) - (12) describe the mathematical model of the signal at the output of the continuous reception channel, taking into account the frequency instability and phase fluctuations of the master oscillators of the carrier and clock oscillations of digital communication lines, the synthesizer of oscillations of the local oscillators of radio receiving systems, the quality of operation of the carrier recovery devices, clock synchronization and automatic gain adjustment.

When determining the requirements for the quality of functioning of the main elements of radio receiving systems, which have the greatest impact on its noise immunity, the following was assumed:

the level of distortion in the transmission path of digital communication lines is comparable with the level of distortion in radio receiving systems;

the frequency response of the continuous channel satisfies the Nyquist condition (7), $\zeta_{x}(t)=0, \zeta_{y}(t)=0$.

\section{Conclusion}

Thus, a mathematical model has been developed and analytical expressions have been obtained that describe the processes of signal conversion in a continuous communication channel with the memory of digital communication lines. It should be noted that methodological approaches to the development of mathematical models of continuous communication channels were proposed in earlier well-known works by the authors A. Viterbi [8], V.I. Korzhik [9], G. Forney [10], J. Stiffler [11], etc. 
However, the originality of the developed model, in contrast to analogues, lies in the fact that it additionally takes into account the following number of factors: frequency instability and phase fluctuations of synthesizer oscillations oscillations of local oscillators, dynamic and static errors of functioning of automatic gain control devices, devices for recovery of carrier oscillations and devices for clock synchronization of radio receiving systems of digital signals.

\section{References}

1. A.G Zyuko (1983). Noise stability and efficiency of communication systems. Moscow: Communication. 320 p.

2. V.V. ablov, D.L. Korobkov, S.L. Portnoy (1991). High-speed message transmission in real channels. Moscow: Radio and communication. 288 p.

3. V.G. Ka ashevsky. (2000). Processing of space-time signals in channels with memory. Moscow: Radio and communication. $272 \mathrm{p}$.

4. D. D. Klov y (1982). Theory of transmission of discrete messages over radio channels. 2nd ed., Rev. and add. Moscow: Radio and communication, 1982. $302 \mathrm{p}$.
5. D. D. Klov y (1973). Theory of signal transmission: textbook. for universities. Moscow: Communication. $376 \mathrm{p}$.

6. V.G. Dov ya, V.E. Aziatsev, S.N. Mikhailov (2017). Noise immunity of radio receiving systems of digital communication lines: monograph. South-West. state un-t. Kursk. 175 p.

7. V.G. Dov ya, D.S. Koptev (2020). Influence of the quality of heterodyne operation on the noise immunity of receiving signals with quadrature amplitude modulation. Radiotekhnika. Vol. 84. No. 9 (17). P. 40-48. DOI: 10.18127 / j00338486-202009 (17) - 03.

8. E. D. Viterbi 1970). Principles of coherent communication. Moscow: Sov.radio. 392 p.

9. V. I. Korzh ， L. M. Fink, K. N. Shchelkunov (1981). Calculation of noise immunity of systems of transmission of discrete messages: a reference book; ed. L. M. Fink. Moscow: Radio and communication. $232 \mathrm{p}$.

10. J. For (1973). Viterbi algorithm. TIIER. Vol. 61. No. 3. P. $12-25$.

11. J. Stiffler 975). Theory of synchronous communication. Moscow: Communication. 488 p. 


\section{МАТЕМАТИЧЕСКАЯ МОДЕЛЬ ПРИЁМНОГО ТРАКТА ЦИФРОВЫХ ЛИНИЙ СВЯЗИ}

Довбня Виталий Георгиевич, Юго-Западный государственный университет, г. Курск, Россия, it_georg@mail.ru Коптев Дмитрий Сергеевич, Юго-Западный государственный университет, г. Курск, Россия, d.s.koptev@mail.ru

\section{Аннотация}

Современные тенденции развития цифровых линий связи фиксированных служб передачи информации, а также характеристики непрерывных каналов на сегодняшний день определяют помехоустойчивость радиоприёмных систем. Основными направлениями её повышения в части радиоприёмного устройства в целом и демодуляторного устройства в частности являются следующие: уменьшение частотных и нелинейных искажений сигнала в линейном тракте, повышение стабильности и чистоты спектральной линии колебаний гетеродинов, повышение избирательности по зеркальному и комбинационным каналам приема, компенсация межсимвольных и кросс-поляризационных помех, повышение качества функционирования устройства автоматической регулировки усиления (уменьшение статической и динамической ошибок), повышение качества функционирования устройства восстановления несущего колебания и устройства тактовой синхронизации. Учёт всех перечисленных выше факторов с целью повышения общей помехоустойчивости цифровой линии связи является весьма сложной и актуальной задачей, решение которой необходимо начинать с разработки математической модели непрерывного канала цифровой линии связи. Рассмотрен радиоприемный тракт цифровой линии связи в условиях городской застройки. Полученные аналитические выражения, направлены на интерпретацию процессов преобразования цифровых сигналов в структурных элементах радиоприёмных систем. Оригинальность разработанной в статье математической модели заключается в том, что она дополнительно, по сравнению с аналогичными моделями, учитывает следующий ряд факторов: частотную нестабильность и фазовые флуктуации колебаний синтезатора гетеродинов, динамическую и статическую ошибки функционирования устройств автоматической регулировки усиления, устройств восстановления несущего колебания и устройств тактовой синхронизации радиоприемных систем цифровых сигналов.

Ключевые слова: математическая модель, радиоприемная система, иифровые линии связи, демодуляторное устройство, устройство восстановления несущей, нестабильность частоты колебаний гетеродина, устройство тактовой синхронизации, потенциальная помехозащищенность.

\section{Литература}

І. Зюко А.Г. Помехоустойчивость и эффективность систем связи. М.: Связь, 1983. 320 с.

2. Зяблов В.В., Коробков Д.Л., Портной С.Л. Высокоскоростная передача сообщений в реальных каналах. М.: Радио и связь, 199 І. 288 с.

3. Карташевский В. Г. Обработка пространственно-временных сигналов в каналах с памятью. М.: Радио и связь, 2000. 272 с.

4. Кловский Д. Д. Теория передачи дискретных сообщений по радиоканалам. 2-е изд., перераб. и доп. М.: Радио и связь, 1982.302 с.

5. Кловский Д.Д. Теория передачи сигналов: учеб. для вузов. М.: Связь, 1973. 376 с.

6. Довбня В.Г., Азиатцев В.Е., Михайлов С.Н. Помехоустойчивость радиоприёмных систем цифровых линий связи: монография. Юго-Зап. гос. ун-т. Курск, 20І7. 175 с.

7. Довбня, В.Г., Коптев, Д.С. Влияние качества функционирования гетеродинов на помехоустойчивость приема сигналов с квадратурной амплитудной модуляцией // Радиотехника. 2020 T. 84 № 9(I7). C. 40-48. DOI: 10.18I27/j00338486-202009(I7)-03.

8. Витерби Э.Д. Принципы когерентной связи: [пер. с англ.]. М.: Сов.радио, 1970. 392 с.

9. Коржик В.И., Финк Л.М., Щелкунов К.Н. Расчет помехоустойчивости систем передачи дискретных сообщений: справочник; под ред. Л. М. Финка.

М.: Радио и связь, 198І. 232 с.

10. Форни Дж. Алгоритм Витерби // ТИИЭР. 1973. Т. 6І. № 3. С. 12-25.

II. Стиффлер Дж. Теория синхронной связи; пер. с англ. Б. С. Цыбакова; ред. Э. М. Габидулина. М.: Связь, 1975. 488 с.

\section{Информация об авторах:}

Довбня Виталий Георгиевич, д.т.н., доцент, профессор кафедры космического приборостроения и систем связи, Юго-Западный государственный университет, г. Курск, Россия

Коптев Дмитрий Сергеевич, аспирант 3-го курса, преподаватель кафедры космического приборостроения и систем связи, Юго-Западный государственный университет, г. Курск, Россия 